\title{
An Efficient and Rapid DNA Minipreparation Procedure Suitable for PCR/SSR and RAPD Analyses in Tropical Forest Tree Species
}

\author{
Ana Lilia Alzate-Marin ${ }^{1 *}$, Marcela Corbo Guidugli ${ }^{1,2,3}$, Hilda Hildebrand Soriani ${ }^{1,2,3}$, \\ Carlos Alberto Martinez ${ }^{2}$ and Moacyr Antônio Mestriner ${ }^{1}$ \\ ${ }^{1}$ Laboratório de Genética Vegetal; Departamento de Genética; Faculdade de Medicina de Ribeirão Preto; Riberão \\ Preto - SP - Brasil. ${ }^{2}$ Departamento de Biologia; Faculdade de Filosofia, Ciências e Letras de Ribeirão Preto; \\ Ribeirão Preto - SP - Brasil. ${ }^{3}$ Universidade de São Paulo; Av. Bandeirantes, 3900; 14049-900; Ribeirão Preto - SP \\ - Brasil
}

\begin{abstract}
An efficient and rapid DNA minipreparation modified method for frozen samples was developed for five tropical tree species: Copaifera langsdorffii, Hymenaea courbaril, Eugenia uniflora, Tabebuia roseo alba and Cariniana estrellensis. This procedure that dispenses the use of liquid nitrogen, phenol and the addition of proteinase K, is an adaptation of the CTAB-based DNA extraction method. The modifications included the use of PVP to eliminate the polyphenols, only one chloroform-isoamyl alcohol step and the addition of RNase immediately after extraction with chloroform. The yields of the DNA samples ranged from 25.7 to $42.1 \mu \mathrm{g}$ from $100 \mathrm{mg}$ leaf tissue. The DNA samples extracted by this method were successfully used for PCR (SSR and RAPD) analyses in these five and other twelve tropical tree species.
\end{abstract}

Key words: Copaifera langsdorffii, Hymenaea courbaril, Eugenia uniflora, Tabebuia roseo alba, Cariniana estrellensis, DNA extraction

\section{INTRODUCTION}

PCR-based methods, such as SSR and RAPD, are widely used in plants for marker-assisted breeding, high-resolution mapping and genetic analysis of populations. Microsatellites or SSR (Simple Sequence Repeat) use specific designed primers based upon the flanking sequences. They are codominant, highly polymorphic and sufficiently informative to enable further studies to characterize the impact of the spatial isolation on gene flow in forest fragments and isolated trees (Ferreira and Grattapaglia, 1995; Ferreira-Ramos et al., 2008). RAPD (Random Amplified Polymorphic DNA) involve the use of a single 'arbitrary' primer. Regardless of its dominant nature and reproducibility problems, the technique has been widely used in many plant population genetic studies due to its high potential to detect the polymorphism (Gillies et al., 1997; Torezan et al., 2005; Goulart et al., 2005). Because these studies require the analysis of large populations, a

*Author for correspondence: anaalzate@ rge.fmrp.usp.br 
DNA extraction method, which could be fast, inexpensive and yielding high quality DNA, is required.

CTAB DNA isolation techniques for extracting the DNA from plant species has been widely used for PCR analysis (Doyle and Doyle, 1990; Kidwell and Osborn, 1992; Ferreira and Grattapaglia, 1995). However, in tree leaf samples, cross contamination of DNA due to secondary metabolites such as terpenes, polyphenols, tannins and polysaccharides, which are often abundant in the foliage of perennials species, were related (Scott and Playford, 1996). As a consequence, many tree species require more complex extraction methods than annual plants (Shepherd et al., 2002).

In this study, an efficient mini-scale DNA extraction method, modified from CTAB procedure (Doyle and Doyle, 1990) for rapid isolation of DNA genomic from five tropical forest tree species, Copaifera langsdorffii, Hymenaea courbaril, Eugenia uniflora, Tabebuia roseo alba and Cariniana estrellensis was developed. The DNA extracted was suitable for PCR and molecular markers (SSR and RAPD) analyses.

\section{MATERIALS AND METHODS}

\section{Plant material}

Leaves samples of $C$. langsdorffii, $H$. courbaril, $E$. uniflora, T. roseo alba and C. estrellensis were collected from ten adult trees of each species growing under field conditions. After collection, the leaves were frozen at $-20{ }^{\circ} \mathrm{C}$.

\section{DNA extraction protocol}

The protocol was standardized for $250-300 \mathrm{mg}$ frozen leaf samples, which could be handled in a 1.7 and $1.5-\mathrm{mL}$ disposable Eppendorf tube. For genomic DNA extraction from frozen leaves, separate experiments for each species were carried out using $900 \mu \mathrm{L}$ of pre-warmed $\left(65^{\circ} \mathrm{C}\right)$ extraction buffer $(2 \%$ w/v CTAB, $1.4 \mathrm{M} \mathrm{NaCl}, 20 \mathrm{mM}$ EDTA, $100 \mathrm{mM}$ Tris-HCl $\mathrm{pH} 8$ and $2 \% \mathrm{w} / \mathrm{v}$ polyvinilpyrrolidone, PVP), with and without Proteinase K $(0.1 \mathrm{mg} / \mathrm{mL})$.

About 250-300 mg of frozen leaf tissue was placed into a porcelain mortar containing $900 \mu \mathrm{L}$ of prewarmed $\left(65^{\circ} \mathrm{C}\right)$ extraction buffer. Immediately after homogenization, the suspension was transferred with micropipette into a $1.7-\mathrm{mL}$ Eppendorf tube. After addition of $2 \% \quad \beta$ - mercaptoethanol, in exhaustion chapel, the samples were mixed thoroughly. The tubes were incubated at $62-65{ }^{\circ} \mathrm{C}$ in a water bath for $30 \mathrm{~min}$ and mixed gently upside down every $10 \mathrm{~min}$. After cooling at room temperature, $800 \mu \mathrm{L}$ of chloroform-isoamyl alcohol mixture (24:1) were added to tubes and mixed gently for approximately $10 \mathrm{~min}$ until the mixture emulsifies. The tubes were centrifuged for $10 \mathrm{~min}$ at 13,200 rpm and the supernatant (aqueous phase) was carefully transferred to a new $1.5 \mathrm{~mL}$ eppendorf tube. After addition of RNase $\mathrm{A}$ in the final concentration of 4 $\mu \mathrm{L} / \mathrm{mL}$, the tubes were incubated at $37{ }^{\circ} \mathrm{C}$ for approximately $30 \mathrm{~min}$. To precipitate DNA, an equal volume of ice-cold isopropanol was added and mixed gently. After incubation at $-20{ }^{\circ} \mathrm{C}$ for 30 minutes (or overnight), the mixture was centrifuged $(13,200 \mathrm{rpm}, 10 \mathrm{~min})$ and the supernatant was discarded. Pellets were washed with $200 \mu \mathrm{L}$ of $70 \%$ ethanol for $5 \mathrm{~min}$. The supernatant was discarded and the DNA was washed again with $200 \mu \mathrm{L}$ of $95 \%$ ethanol for 2 min. The ethanol was removed and tubes were stored for 15 minutes at room temperature in order to dry the DNA. Finally, the DNA was dissolved in 200-300 $\mu \mathrm{L}$ TE buffer (10 mM Tris- $\mathrm{HCl} \mathrm{pH} 8$; $1 \mathrm{mM}$ EDTA pH 8) and stored at $-20^{\circ} \mathrm{C}$ until use.

\section{DNA purity and concentration detection}

The quality of total DNA extracted was observed in agar gels $1 \%$. The DNA was diluted with TE buffer. The absorbance at $260 \mathrm{~nm}$ and $280 \mathrm{~nm}$ were measured in a spectrophotometer (Spectronic Genesys 5). DNA purity was judged by the absorbance ratio of A260/A280. The DNA concentration was calculated from the $260 \mathrm{~nm}$ absorbance: [DNA] $\mu \mathrm{g} / \mu \mathrm{L}=\left(\mathrm{A}_{260} * \mathrm{f} * 50\right) / 1000$, where $\mathrm{f}$ was a dilution factor, and $50 \mu \mathrm{g} / \mathrm{mL}$ corresponded to one optic density unit (Sambrook et al., 1989).

\section{DNA amplification}

Amplification reactions were performed in a thermocycler (model Eppendorf). Each reaction $(10 \mu \mathrm{l})$ contained $25 \mathrm{ng}$ of DNA, $0.25 \mathrm{mM}$ of each dNTP, $1.5 \mathrm{mM} \mathrm{MgCl} 2,0.12$ unit of Taq DNA polymerase (Biotools), 1X reaction buffer Biotools [75 mM Tris- $\mathrm{HCl}, \mathrm{pH} 9.0 ; 50 \mathrm{mM} \mathrm{KCl}, 20 \mathrm{mM}$ $\left.\left(\left(\mathrm{NH}_{4}\right)_{2} \mathrm{SO}_{4}\right)\right] ; \quad 0.3 \mu \mathrm{M}$ of each primer microsatellite (Bio-Synthesis - USA) or $0.4 \mu \mathrm{M}$ of one primer decamer RAPD (Bioneer, Denmark). The description of SSR and RAPD primers used for amplification is shown in Table 1 . 
For SSR molecular markers amplification, the PCR program used was an initial strand separation at 94 ${ }^{\circ} \mathrm{C}$ for $5 \mathrm{~min}$, followed by 29 cycles of denaturation at $94{ }^{\circ} \mathrm{C}$ for $1 \mathrm{~min}$, annealing at $52-60{ }^{\circ} \mathrm{C}$ for $1 \mathrm{~min}$ and elongation at $72{ }^{\circ} \mathrm{C}$ for $1 \mathrm{~min}$; with a final extension at $72{ }^{\circ} \mathrm{C}$ for $10 \mathrm{~min}$. Allelic polymorphism was detected in $10 \%$ denaturing polyacrylamide gels and visualized by silver staining (Sanguinetti et al., 1994). For RAPD molecular markers amplification each cycle consisted of one denaturation step at $94{ }^{\circ} \mathrm{C}$ for 15 $\mathrm{s}$, one annealing step at $35{ }^{\circ} \mathrm{C}$ for $30 \mathrm{~s}$, and one extension step at $72{ }^{\circ} \mathrm{C}$ for $1 \mathrm{~min}$. After 40 cycles, an extra extension step was performed for $7 \mathrm{~min}$ at $72{ }^{\circ} \mathrm{C}$. The DNA fragments amplified by RAPD were detected on $8 \%$ non-denaturing polyacrylamide gels and visualized by silver staining (Sanguinetti et al., 1994).

Table 1 - Primers SSR and RAPD used in the amplification of some tropical forest tree species.

\begin{tabular}{|c|c|c|c|c|c|}
\hline Loci & Sequence & Replicate & $\begin{array}{c}\text { PCR } \\
\text { Product (bp) }\end{array}$ & Species & Reference \\
\hline HC33 & - & $(\mathrm{AG})_{16}$ & $124-160$ & H. courbaril & $\begin{array}{l}\text { Ciampi et al. } \\
\text { (2008) }\end{array}$ \\
\hline Pit06 & - & $(\mathrm{TC})_{25}$ & $88-245$ & E. uniflora & $\begin{array}{l}\text { Ferreira- } \\
\text { Ramos, R. }\end{array}$ \\
\hline CL01 & $\begin{array}{l}\text { F: 5'AGACTCCATTCTTCCACAGC3' } \\
\text { R: 5'CTGTCTTCTCTCTGCAACCA3' }\end{array}$ & $(\mathrm{AG})_{24}$ & $174-226$ & C. langsdorffii & $\begin{array}{l}\text { Ciampi et al. } \\
\text { (2000) }\end{array}$ \\
\hline Tau21 & $\begin{array}{l}\text { F: 5'CTTTTGGGGGTCTTTGGAAT3' } \\
\text { R: 5'GAAAGAGACAGAGACAAAGATACA3' }\end{array}$ & $(\mathrm{GA})_{26}$ & 238 & T. roseo alba & $\begin{array}{l}\text { Braga et al. } \\
\quad \text { (2007) }\end{array}$ \\
\hline $\begin{array}{l}\text { RAPD } \\
\text { OPB04 }\end{array}$ & 5'GGACTGGAGT3' & - & - & $\begin{array}{l}\text { E. uniflora } \\
\text { T. roseo alba }\end{array}$ & - \\
\hline $\begin{array}{l}\text { RAPD } \\
\text { OPB09 }\end{array}$ & 5'TGGGGGACTC3' & - & - & H. courbaril & - \\
\hline $\begin{array}{l}\text { RAPD } \\
\text { OPB } 10\end{array}$ & 5'CTGCTGGGAC3' & - & - & $\begin{array}{l}\text { C. estrellensis } \\
\text { P. nitens } \\
\text { P. elegans } \\
\text { A. macrocarpa } \\
\text { H. balansae } \\
\text { C. domentosoum } \\
\text { M. peruiferum } \\
\text { S. parahyba } \\
\text { M. villosum } \\
\text { C. ferrea } \\
\text { P. regnelli } \\
\text { E. contorsiliquum } \\
\text { A. polyphylla }\end{array}$ & , \\
\hline
\end{tabular}

ada not published

\section{RESULTS AND DISCUSSION}

Several different methods and technologies are available for the isolation of plant genomic DNA, however, the better results can be observed with those based in use of CTAB (Doyle and Doyle, 1990; Kidwell and Osborn, 1992; Ferreira and Grattapaglia, 1995; Dilworth and Frey, 2000; Shepherd et al., 2002; Kang and Yang, 2004; Narayanan et al., 2006). In general, all methods consists of the following major steps: (1) grinding of samples, (2) phenol:chloroform:isoamyl alcohol extraction, and (3) DNA precipitation. The choice of a specific method depends on many factors: the required quantity and molecular weight of the DNA, the purity required for downstream applications, the time and the expense. The protocol described in this work was an adaptation from the DNA isolation method described by Doyle and Doyle (1990), Ferreira and Grattapaglia (1995) and Agwanda et al. (1997). In this modified method, the use of liquid nitrogen and phenol has 
been avoided. According to Scott and Playfford (1996), grinding samples with liquid nitrogen can produce degradation of DNA. The phenol is suspected to induce the mutagenesis (Huberman et al., 1971). The adaptation of the CTAB extraction procedure also includes: 1) the use of polyvinylpyrrolidone (PVP) to remove the polyphenols and prevent oxidation of the secondary metabolites in plant tissues (as proposed by Ferreira and Grattapaglia, 1995), 2) only one extraction step with chloroform-isoamyl alcohol, and (3) the implementation of RNase treatment after extraction with chloroform and before precipitating the DNA with cold isopropanol (as proposed by Agwanda et al., 1997).

The necessity of Proteinase K, frequently used for DNA extraction due to its efficiency for digestion of nuclei or whole cells and release of DNA for the action of polymerases (Cabral et al., 2000), was tested in this work. Minor differences were found in quality and yields of DNA frozen samples with and without Proteinase K. For the five tree species, the average of values A260/A280 oscillated between 1.13 and 1.14, with and without
Proteinase K, respectively, suggesting low level of contamination with proteins (Table 2). The extracted DNA was not degraded and contained no RNA contamination (Fig. 1). The yields of the DNA samples ranged from 25.7 to $42.1 \mu \mathrm{g}$ from $100 \mathrm{mg}$ leaf tissue, enough to conduct 1000 PCRs. This DNA extraction method, excluding the Proteinase K, was also tested with frozen and fresh samples of E. uniflora (Table 3). About 17\% higher DNA concentration was obtained from fresh samples than frozen material. However, both fresh and frozen samples from E. uniflora yielded genomic DNA of high molecular weight that was not degraded. In addition, all the samples of DNA extracted without the use of Proteinase $\mathrm{K}$ were successfully used for PCR-based marker analysis, such as SSR and RAPD (Fig. 2). Moreover, this methodology also worked very well for extracting the DNA from leaves of other twelve leguminous forest species, besides the species tested in this work (Table 2). The DNA of the leguminous species was amplified with primer RAPD OPB10 (Fig.-3).

Table 2 - Average values of the purity and concentration of the extracted DNA from 17 tropical forest tree species.

\begin{tabular}{cccccc}
\hline & & With Proteinase K & \multicolumn{2}{c}{ Without Proteinase K } \\
\cline { 3 - 6 } Species & Common name & D260/A280 & $\begin{array}{c}\text { DNA } \\
(\mathbf{n g} / \boldsymbol{\mu L} \text { ) }\end{array}$ & $\mathbf{A 2 6 0 / A 2 8 0}$ & $\begin{array}{c}\text { DNA } \\
\text { (ng/ } \mathbf{\mu L})\end{array}$ \\
\hline Copaifera. langsdorffii & Óleo de Copaíba & 1.20 & 400 & 1.10 & 333 \\
Hymenaea courbaril & Jatobá & 1.21 & 440 & 1.20 & 366 \\
Eugenia uniflora & Pitanga & 1.10 & 322 & 1.11 & 345 \\
Tabebuia roseo alba & Ipê Branco & 1.10 & 340 & 1.12 & 539 \\
Cariniana estrellensis & Jequitibá Branco & 1.03 & 304 & 1.15 & 537 \\
Pterogyne nitens & Amendoim Bravo & - & - & 1.22 & 526 \\
Platycyamus elegans & Amendoim do Campo & - & - & 1.13 & 388 \\
Anadenanthera macrocarpa & Angico & - & - & 1.10 & 374 \\
Holocalyx balansae & Alecrim de Campinas & - & - & 1.20 & 413 \\
Centrolobioum domentosoum & Araribá & - & - & 1.10 & 471 \\
Myroxylum peruiferum & Cabreuva & - & - & 1.12 & 367 \\
Schizolobium parahyba & Guapuruvu & - & - & 1.03 & 358 \\
Machaerum villosum & Jacarandá do Mato & - & - & 1.10 & 369 \\
Caesalpinea ferrea & Pau Ferro & - & - & 1.20 & 443 \\
Platycyamus regnelli & Pau Pereira & - & - & 1.23 & 455 \\
Entherolobium contorsiliquum & Tamboril & - & - & 1.23 & 530 \\
Acacia polyphylla & Monjoleiro & - & - & 1.30 & 530 \\
\hline
\end{tabular}






Figure 1 - Genomic DNA extracted from frozen leaves of C. langsdorffii (1-2), H. courbaril (3-4), E. uniflora (5-6), T. roseo alba (7-8) and C. estrellensis (9-10). Lanes 1, 3, 5, 7, 9 and 2, 4, 6, 8, 10, correspond to DNA extracted with and without Proteinase K, respectively. Lane M corresponds to 50 base-pair ladder (Amersham).

Table 3 - DNA purity and concentration detection of frozen and fresh samples from E. uniflora. The DNA extractions were carried out without Proteinase K. The average represent mean values \pm SE $(n=10)$. The mean difference in DNA purity between frozen and fresh material was not statistically significant but, the mean DNA concentration was just statistically significant (paired sample t test, $\mathrm{P}=0.05$ ).

\begin{tabular}{|c|c|c|c|c|}
\hline \multicolumn{3}{|c|}{ E. uniflora-frozen } & \multicolumn{2}{|c|}{ E. uniflora-Fresh } \\
\hline$\#$ & A260/A280 & DNA ng/ $\mu \mathrm{L}$ & A260/A280 & DNA ng/ $\boldsymbol{\mu L}$ \\
\hline 1 & 1.02 & 292.383 & 1.09 & 366.520 \\
\hline 2 & 1.05 & 304.878 & 1.12 & 400.256 \\
\hline 3 & 1.18 & 372.351 & 1.13 & 437.325 \\
\hline 4 & 1.11 & 339.447 & 1.09 & 458.150 \\
\hline 5 & 1.10 & 341.946 & 1.08 & 345.278 \\
\hline 6 & 1.06 & 297.381 & 1.14 & 419.832 \\
\hline 7 & 1.07 & 303.212 & 1.07 & 346.944 \\
\hline 8 & 1.07 & 335.282 & 1.11 & 361.522 \\
\hline 9 & 1.09 & 318.206 & 1.09 & 358.190 \\
\hline 10 & 1.08 & 316.540 & 1.10 & 376.932 \\
\hline Average & $1.083 \pm 0.012$ & $322.163 \pm 7.879$ & $1.102 \pm 0.011$ & $387.095 \pm 12.558$ \\
\hline
\end{tabular}

Since this DNA extraction method did not require liquid nitrogen, phenol, proteinase $\mathrm{K}$ or any expensive commercial DNA extraction kits, it would be less expensive than other methods. Using this protocol in a single day, one can complete DNA isolation from more than 50 leaf samples. This method has been routinely used to extract DNA from tropical forest tree species in our laboratory. We have used this DNA extraction procedure for screening approximate two hundred trees of species $C$. langsdorffii, E. uniflora, $T$. roseo alba and $H$. courbaril using SSR primers. Reproducible SSR amplification was observed in PCR reactions in all independent extractions and replicates. Also, RAPD reactions were conducted with approximately 10 different samples of $E$. uniflora, $T$. roseo alba, $H$. courbaril and $C$. estrellensis species using the primers RAPD OPB04, OPB09 and OPB10. Different RAPD fingerprints among individuals of the same species 
(Fig. 2b and 2c) and the other twelve leguminous species (Fig. 3) were observed. These results were expected because the high degree of intraspecific genetic variation found within the tropical forest species assessed with RAPD molecular markers (Gillies et. al, 1997; Torezan et al., 2005; Goulart et al., 2005). However, the reproducibility of RAPD fingerprints must be tested in separate experiments. This improved DNA extraction procedure from fresh tissue was recently used with success for development of genomic library of $E$. uniflora and $C$. estrellensis (data not shown).



Figure 2 - Electrophoretic analysis of amplification products obtained with SSR and RAPD primers. A) Lanes 2-4, 5-7, 8-10 and 11-13 are DNA samples of E. uniflora, $C$. langsdorffii, T. roseo alba and $H$. courbaril species amplified with SSR primers Pit06, CL01, Tau21 and HC33, respectively. B) Lanes 2-6 are DNA samples of $H$. courbaril amplified with RAPD primer OPB09 and C) Lanes 1-3 are DNA samples of C. estrellensis amplified with RAPD primer OPB10. Lanes 1 (Fig. A and B) and 4 (Fig. C) corresponds to 50 base-pair ladder (Amersham).

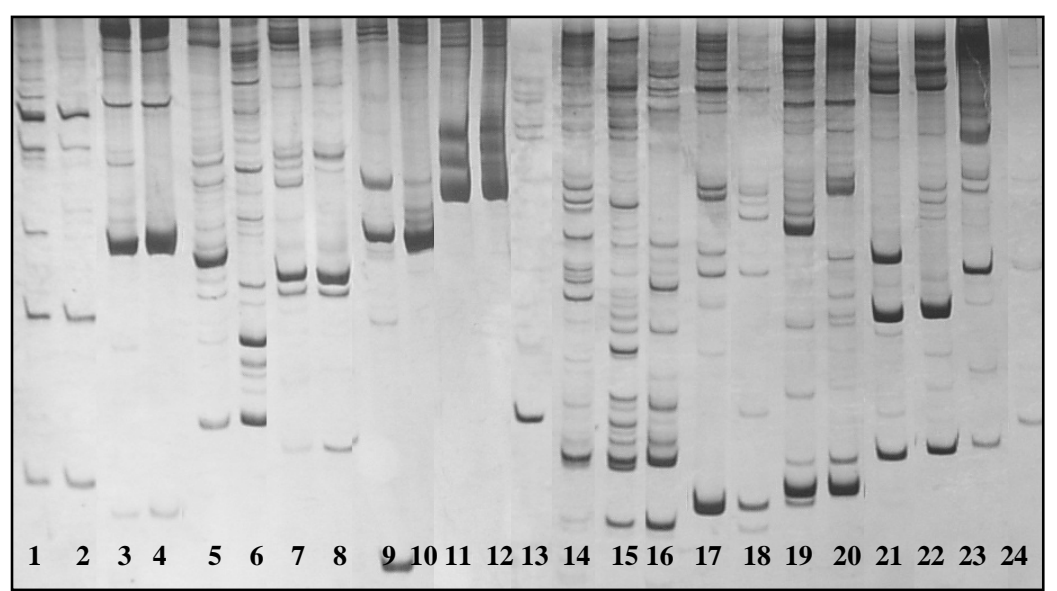

Figure 3 - DNA samples from two mature tree of twelve different leguminous species amplified with RAPD primer OPB10: P. nitens (1-2), P. elegans (3-4), A. macrocarpa (5-6), $H$. balansae (7-8), C. domentosoum (9-10), M. peruiferom (11-12), S. parahyba (13-14), M. villosum (15-16), C. ferrea (17-18), P. regnelli (19-20), E. contorsiliquum (21-22) and A. polyphylla (23-24). 
In summary, the procedure described here could be a reliable and consistent protocol to work well for extracting DNA and analysis of large populations from $C$. langsdorffii, $H$. courbaril, $E$. uniflora, T. roseo alba and $C$. estrellensis tree species and should be widely applicable for DNA analysis from other tropical forest tree species.

\section{ACKNOWLEDGEMENTS}

This work was financed by a grant from the São Paulo state government to ALAM: FAPESP 03/04199-4/2004. MCG was supported by a posgraduation scholarship from CAPES. HHS was supported by an undergraduate scholarship from CNPq. ALAM was supported by a research fellowship from FAPESP. CAM is CNPq research fellow. We also acknowledge the support of the Research Pro-Rectory of São Paulo University (USP) to ALAM and FAEPA to MAM.

\section{RESUMO}

Este trabalho teve como objetivo otimizar um protocolo econômico, rápido e eficaz de minipreparação de DNA genômico, para as espécies florestais Copaifera langsdorffii (Óleo de Copaíba), Hymenaea courbaril (Jatobá), Eugenia uniflora (Pitanga), Tabebuia roseo alba (Ipê Branco) e Cariniana estrellensis (Jequitibá Branco). Este método é uma adaptação da técnica de extração CTAB de Doyle e Doyle (1990), o qual consiste principalmente na adição de PVP para eliminar polifenoles, somente uma etapa de extração com clorofórmio-álcool isoamílico e a adição da RNase A imediatamente após a extração com clorofórmio. O método também dispensa o uso de nitrogênio líquido, o uso do fenol e a adição de proteinase K. Os DNAs das espécies florestais extraídos apresentaram alto rendimento e boa qualidade, com rendimento de 25.7 a $42.1 \mu \mathrm{g}$ de DNA a partir de $100 \mathrm{mg}$ de tecido foliar congelado. Com este protocolo, em apenas 1 dia de trabalho, uma pessoa pode completar o isolamento do DNA de aproximadamente 50 amostras de folhas (dependendo da capacidade da centrífuga). O DNA obtido pode ser usado para métodos de análise baseados em PCR (SSR e RAPD).

\section{REFERENCES}

Agwanda, C. O.; Lashermes, P.; Trouslot, P.; Combes, M. C. and Charrier, A. (1997), Identification of RAPD markers for resistance to coffee berry disease, Colletotrichum kahawae, in arabica coffee. Euphytica, 97, 241-248.

Braga, A. C.; Reis, A. M. M.; Leoi, L. T.; Pereira, R.W. and Collevatti, R. (2007), Development and characterization of microsatellite markers for the tropical tree species Tabebuia aurea. Mol Ecol Notes, 7, 53-56.

Ciampi, A. Y.; Brondani, R. P. V. and Grattapaglia, D. (2000), Desenvolvimento de Marcadores Microssatélites para Copaifera langsdorfii Desf. (Copaíba) - Leguminosae-Caesalpinoideae $e$ Otimização de Sistemas Fluorescentes de Genotipagem Multiloco. Embrapa Recursos Genéticos e Biotecnologia, Brasília.

Ciampi, A. Y.; Azevedo, V. C. R.; Gaiotto, F. A.; Ramos, A. C. S. and Lovato M. B. (2008), Isolation and characterization of microsatellite loci for Hymenaea courbaril and transferability to Hymenaea stigonocarpa, two tropical timber species. Mol Ecol Res, 8, 1074-1077.

Cabral, H.; Ruiz, M. T.; Carareto, C. M. A. and BonillaRodriguez, G. O. (2000), A plant proteinase, extracted from Bromelia fastuosa, as an alternative to proteinase K for DNA extraction. Dros. Inf. Serv., 83, 178-185.

Doyle, J. J. and Doyle, J. L. (1990), Isolation of plant DNA from fresh tissue. Focus, 12, 13-15.

Dilworth, E. and Frey, J. E. (2000), A Rapid Method for High Throughput DNA Extraction from Plant Material for PCR Amplification. Plant Mol. Biol. Rep., 18, 61-64.

Ferreira, M. E. and Grattapaglia, D. (1995), Introdução ao uso de marcadores moleculares em análise genética. EMBRAPA-CENARGEN, Brasília.

Ferreira-Ramos R.; Laborda P. R.; Oliveira Santos M.; Mayor M. S.; Mestriner, M. A.; Souza, A. P.; AlzateMarin A. L. (2008), Genetic analysis of forest species Eugenia uniflora L. through of newly developed SSR markers. Conserv. Genet., 9, 1281-1285.

Gillies A. C. M.; Cornelius J. P.; Newton A. C.; Navarro C.; Hernández M. and Wilson J. (1997), Genetic variation in Costa Rican populations of the tropical timber species Cedrela odorata L. (Spanish Cedar), assessed using RAPDs. Mol. Ecol., 6, 11331145.

Goulart, M. F.; Ribeiro, S. P. and Lovato, M. B. (2005), Genetic, Morphological and Spatial Characterization of two Populations of Mabea fistulifera Mart. (Euphorbiaceae), in Different Successional Stages. Braz. Arch. Biol. Techn., 48, 275-284. 
Huberman, E.; Aspiras, E.; Heidelberger, C.; Grover, P. L. and Sims, P. (1971), Mutagenicity to Mammalian Cells of Epoxides and other Derivatives of Polycyclic Hydrocarbons. PNAS., 68, 3195-3199.

Kang, T. J. and Yang, M. S. (2004), Rapid and reliable extraction of genomic DNA from various wild-type and transgenic plants. BMC Biotechnol., 4, 20.

Kidwell, K. K. and Osborn, T. C. (1992), Simple plant DNA isolation procedures. In-Plants Genomes: Methods for genetic and Physical Mapping, eds. J. S. Beckmann and T. C. Osborn. Kluwer Academic Publishers, Netherlands, pp. 1-13.

Narayanan, C.; Dubey, S.; Wali, S. A.; Shukla, N.; Kumar, R.; Mandal, A. K. and Ansari, A.S. (2006), Optimization of DNA extraction for ISSR studies in Tectona grandis L.f. - an important forest tree species. African Journal of Biotechnology, 5, 12201223.

Sambrook, J.; Maniatis, T. and Fritsh, E. F. (1989), Molecular cloning: a laboratory manual. Cold Spring Harbor Laboratory Press, New York.
Sanguinetti, C. J.; Dias, E. N. and Simpson, A. J. G. (1994), Rapid silver staining and recovery of PCR products separated on polyacrylamide gels. Biotech., 17, $914-921$.

Scott K. D and Playford J. (1996), DNA extraction technique for PCR in rainforest plant species. BioTechniques, 20, 974-978.

Shepherd, M.; Cross, M.; Stokoe, R. L.; Scott, L. J. and Jones, M. E. (2002), High-Throughput DNA Extraction From Forest Trees. Plant Mol. Bio. Rep., 20, 425-425.

Torezan, J. M. D.; Souza, R. F.; Ruas, P. M.; Ruas, C. F.; Camargo E. H. and Vanzela A. L. L. (2005), Genetic Variability of Pre and Post-Fragmentation Cohorts of Aspidosperma polyneuron Muell. Arg. (Apocynaceae). Braz. Arch. Bio. Techn., 48, 171-180.

Received: July 10, 2007; Revised: February 01, 2008; Accepted: January 19, 2009. 